\title{
The Implementation of Limited Direct Learning Method in Madrasah to Support Students' Literacy
}

\author{
Andarusni Alfansyur ${ }^{1 *}$, Muhammad R. Hadiyan ${ }^{2}$ \\ ${ }^{I}$ Madrasah Aliyah Negeri 3 Palembang, Palembang, Indonesia \\ ${ }^{2}$ Department of International Relations, Universitas Airlangga, Surabaya, Indonesia \\ "Corresponding author. Email: aandarusni@gmail.com
}

\begin{abstract}
After being implemented for more than one year due to the pandemic, educational institutions in Indonesia could switch online learning to the hybrid learning method. The implementation of this transitional learning mode would face several challenges, especially for Islamic boarding schools. This study uses a qualitative approach and the method of case studies to reveal the ongoing implementation of the new learning method as well as its supporting factors and obstacles. Data is obtained through primary and secondary sources, including interviews, participative observation, and documentation in Public Madrasah Aliyah (MAN) 3 Palembang. The Islamic boarding school might face several difficulties to build back the students' discipline, student's literacy and the adaptation process would slightly take a longer time. At the end, several recommendations are stated for different subjects including the policy-makers, school residents, dormitory regulators, parents, and government.
\end{abstract}

Keywords: Implementation, Adaptation, Direct learning method, Islamic boarding school, Students' literacy.

\section{INTRODUCTION}

Since the beginning of the Covid-19 pandemic, most of the countries have been forced to switch to technology and online method for some sectors leading to struggle for adaptation, including the education sector. UNESCO reported that more than 1.9 billion students from 190 countries have been obligated to adapt quickly. However, the adaptation process in developing countries would take a longer period compared to the advanced ones; Indonesia is no exception [1]. That slow adaptation caused many transformations while the government released various policies to sustain the educational sector in Indonesia [2].

At the beginning of the pandemic, the schools and all of the related activities were stopped. The policy raised questions concerning how Indonesia would continue the teaching process amid an unpredictable situation. Due to the pandemic and social restriction, the educational activities should be switched the learning modes from face-to-face to online learning using various media [3]. The main concern was prioritizing the health condition of participating students, teachers, families, and society in general. The policy has been implemented in every levels of educational institution, including madrasah.
However, previous studies revealed that Indonesia could not rely on its online learning system for such a long time. The learning process might be slightly ineffective, and therefore, could not reach its desired targets [4]. For madrasah, the target to measure how successful the learning process itself is just not limited to scientific comprehension of its student, but also expanding to the practice of the Islamic values of life and develop literacy. Moreover, madrasah that are integrated with the boarding school system have double fundamental roles in developing Islamic values over the surrounding communities [5]. From prior explanations, it is understandably acknowledged that the switch to the online learning method could be challenging for the madrasah with an integrated system to boarding school.

This study is situated in one public madrasah Aliyah (senior secondary) integrated to a dormitory known as Islamic boarding school in Palembang, Indonesia. As Covid-19 cases in Palembang decreased, the local Ministry of Religious Affairs has issued multiple policies that madrasah may switch their online learning mode to hybrid learning mode. The implementation of the transitional hybrid learning mode has been conducted since July 12th, 2021. 
There are several considerations for the madrasah to quickly switch to a hybrid learning method. From the perspective of several students' parents, letting their children stay at the dormitory would be much safer. At the dormitory, the students would be fully observed. They are also obligated to spend 24 hours within the dormitory and school complex and could not easily leave the site without getting any permission. Compared to the condition while staying in their respective houses, a lot of parents admitted that their children have been bored in facing the pandemic that even increases their will to mingle with their friends. Thus, the parents prefer to send their children to the dormitory based on the policy applied at the madrasah.

From the teachers' perspective, most of the teachers support the decision to switch to a hybrid learning method considering the effectiveness of the learning process. A lot of teachers admitted that most of the students do not put much attention to their learning materials during online classes. Furthermore, several students are not having much concern about the aim of the learning. Instead, their participation is just to complete their required attendance.

Therefore, regarding prior explanations, this paper aims to describe the implementation of the hybrid learning modes in Indonesian madrasah, find the implications of the hybrid learning method in multiple activities, and explain the supporting factors as well as the obstacles. The Ministry of Religious Affairs has provided some specified indicators to review the implementation of hybrid learning methods, i.e. the preparation of learning facilities and infrastructures, paradigm, religious activities, interaction pattern, and learning pattern [6].

\section{METHODS}

This is a qualitative study with a case study approach based on the focus of this study to completely explain or describe a phenomenon of the transitional learning mode at the madrasah. Data were obtained through primary and secondary sources. The primary sources were the results of semi-structured interviews with the principals, the head of the dormitory, and the representatives of both teachers and students of one Public Madrasah Aliyah (MAN) 3 Palembang. The secondary sources were the results of participative observation and documentation regarding the implementation of the hybrid learning modes at the madrasah. To analyze the data, this study used three methods, namely reducing, presenting, and drawing conclusions as well as recommendations [7].

\section{RESULTS AND DISCUSSION}

\subsection{The Profile of MAN 3 Palembang}

MAN 3 Palembang is one of Indonesian madrasahs that has implemented hybrid learning method through its boarding school system established in 1991 as Islamic Teacher School. In 2006, MAN 3 Palembang was allowed to open an integrated Islamic boarding school system (pesantren), known as "Pondok Pesantren AlIhsan MAN 3 Palembang". Despite its integration into the school system, Pondok Pesantren Al-Ihsan MAN 3 Palembang has different and separated management led by a headmaster of the boarding school (or mudirul ma'had). In 2021, however, a set of new regulations issued by the Ministry of Religious Affairs allows the pesantren to be integrated into MAN 3 Palembang under one management system directly led by the school principal.

The Islamic Boarding School of MAN 3 Palembang provides three different complexes of the dormitory, consisting male dormitory, female dormitory, a dormitory for $11^{\text {th }}$ and $12^{\text {th }}$ grade students. All $10^{\text {th }}$ grade students are ordered to stay at the dormitory for at least one year. That order is based on a consideration to develop students' discipline mentality and ease their adaptation process. The dormitory facility is specifically also open for selected $11^{\text {th }}$ and $12^{\text {th }}$ grade students that originated from various regions outside Palembang. In total, there are 420 students that stay within the dormitory for the academic year of $2021 / 22$. That number could be divided into 141 males, 212 females, and $6711^{\text {th }}$ and $12^{\text {th }}$ grade students.

\subsection{The Hybrid Learning Method in MAN 3 Palembang}

\subsubsection{The Preparation Process}

The preparation process to implement the hybrid learning method in MAN 3 Palembang had been started months since the official announcement. MAN 3 Palembang has registered all of the teaching staff, administrators, and mentors both in the school and dormitory for the Covid-19 vaccination program. Getting all of staffs to be fully vaccinated is one of the requirements set by the government to implement hybrid learning.

Weeks before school and dormitory re-opening, MAN 3 Palembang held a special meeting led by the principal attended by all of the teaching staffs, dormitory mentors, the school committee as the representation of the students' parents, and local Covid-19 Task Force. The expected result of that meeting was to establish a comprehensive plan that would become the SOP of the hybrid learning method [8]. All of the meeting participants fully acknowledged that the implementation of the hybrid learning method should comply the physical health protocol, such as physical distancing, and the school has been committed to improving and providing 
more facilities and infrastructures for both school and dormitory, including:

- Opening a new dormitory building for $11^{\text {th }}$ and $12^{\text {th }}$ grade students located beside the main school building.

- Increasing the number of rooms for both male and female dormitories. To increase the number of rooms, MAN 3 Palembang reused several old classrooms and filled them with dormitory stuff such as beds, wardrobes, and water sanitation.

- Expanding the dormitory's kitchen and dining room.

- Providing new handwashing facilities in multiple spots for both school and the dormitory.

- Providing a new self-isolation room in the dormitory for sick students who are unable to return to their homes.

MAN 3 Palembang also orders all of the dormitory mentors to check their students' daily body temperature before going to the school. All of the students in the dormitory are provided with a new set of masks and hand sanitizer every Sunday. They are also registered for the Covid-19 vaccination program held at the school hall. Regarding the vaccination program, MAN 3 Palembang expected that all of the students would have their second jabs of the Covid-19 vaccine at the end of November 2021.

However, as the implementation of hybrid learning is underway, infrastructure is still one of the challenges that they have to face. In terms of the required health protocols, weekly free mask supplies for the students are sometimes not sufficient. While in the male dormitory, new handwashing facilities may have been installed, but contribution by providing the required facilities directly or through a financial donation. The support of the parents was believed to be one of the most critical supporting factors in the implementation of hybrid learning methods at the school.

\subsubsection{Paradigm}

Paradigm could be defined as a basic set of beliefs that guide action [9]. In terms of the educational paradigm, it is defined as a set of the basic assumption that guides all of the behaviors and attitudes to sustain the education process [10].

The pandemic has triggered a lot of transformation across sectors including education. Therefore, there is also a shift in the educational paradigm, not just for the students, but also for all of the teaching staff, administrators, parents, and school regulators. Previously, the paradigm shift takes place to transform the learning method into more technology-oriented, a period that is called as "a new normal". Currently, as the hybrid learning method begins to be implemented at schools, experts argue that this period could be called as post-COVID era [11]

During the online remote learning period, the dormitory was not operated and fully closed. All of the students and teaching staff attended the classes from home. Therefore, returning to the dormitory required a paradigm shift not just for the students, but also for the teaching staff and dormitory mentors. According to the principal of MAN 3 Palembang, she encouraged all of the relevant subjects within the institution to be adaptive and

Table 1. Paradigms

\begin{tabular}{|c|c|c|}
\hline $\begin{array}{l}\text { Responsible } \\
\text { Subjects }\end{array}$ & Before the Pandemic (Normal Situation) & During Hybrid Learning Implementation \\
\hline \multirow{3}{*}{ Students } & $\begin{array}{c}\text { Obeying all of the school regulations through } \\
\text { the force of the school's teaching staff and } \\
\text { dormitory mentors }\end{array}$ & $\begin{array}{l}\text { Improving their own self-awareness to comply with } \\
\text { the regulations, including the health protocol. }\end{array}$ \\
\hline & $\begin{array}{c}\text { Having limitless interaction during regular } \\
\text { classes }\end{array}$ & $\begin{array}{c}\text { Having similar interaction with their fellow friends, } \\
\text { while paying attention to physical distancing } \\
\text { regulation }\end{array}$ \\
\hline & $\begin{array}{l}\text { Showing more attention to the lessons } \\
\text { delivered by the teaching staff }\end{array}$ & $\begin{array}{l}\text { Having the ability to learn all of the available lessons } \\
\text { independently, in the classes, the dormitory, and } \\
\text { multiple courses }\end{array}$ \\
\hline $\begin{array}{l}\text { Dormitory } \\
\text { Mentors }\end{array}$ & Prioritizing students' discipline and punctuality & $\begin{array}{l}\text { Taking care of the students' discipline as well as } \\
\text { prioritizing their health condition }\end{array}$ \\
\hline
\end{tabular}

the water supply has been sometimes exhausted. To solve those problems, most of the students' parents voluntarily assisted the school by sending mask supplies for their children. Some of the parents also showed their shifted some of the paradigms as could be seen through Table 2. 
Table 2. Respond for learning

\begin{tabular}{|c|c|c|}
\hline $\begin{array}{l}\text { Responsible } \\
\text { Subjects }\end{array}$ & Before the Pandemic (Normal Situation) & During Hybrid Learning Implementation \\
\hline \multirow[t]{2}{*}{ Teachers } & $\begin{array}{l}\text { Developing their teaching ability through } \\
\text { good communication skills and other } \\
\text { conventional methods }\end{array}$ & $\begin{array}{l}\text { Developing their communication skill through both } \\
\text { conventional and online infrastructures as well as } \\
\text { improving their technology and digital literation }\end{array}$ \\
\hline & $\begin{array}{l}\text { Focusing the class only on their teaching } \\
\text { materials }\end{array}$ & $\begin{array}{l}\text { Paying more attention to students' hygiene before, } \\
\text { during, and after the class }\end{array}$ \\
\hline $\begin{array}{l}\text { Parents or } \\
\text { Guardians }\end{array}$ & $\begin{array}{l}\text { Providing assistance for the students in non- } \\
\text { technical issues }\end{array}$ & $\begin{array}{l}\text { Providing assistance for the students to furtherly } \\
\text { comprehend their school's lessons as well as their } \\
\text { health condition }\end{array}$ \\
\hline
\end{tabular}

The principal of MAN 3 Palembang admitted that the shift of the paradigm from the normal situation to the implementation of hybrid learning cannot happen instantly or smoothly. Some of the teachers revealed that most of the students missed on most of their lessons and could not learn independently. Therefore, the principal stated that to ease the paradigm shift, all of the responsible subjects (as mentioned in the table) should be working hand-in-hand and cooperatively. She also added that having a proper paradigm is one of the keys to the implementation of hybrid learning successfully at MAN 3 Palembang.

\subsubsection{Religious Activities}

As one of the providers of Islamic education, a set of religious activities or worshipping is one of the most essential things in MAN 3 Palembang. There are several definitions of worship. One of the most popular definitions stated that worship is all of the actions and behaviors liked and blessed by God. In a practical context, Islamic worship includes salat, zikir, wudhu, taharah, and many other forms [12].

During the outbreak of the Covid-19 pandemic, worshipping activities were also disrupted. The procedures of worship also transformed from "on-site" to "online" [13]. However, in MAN 3 Palembang, as the dormitory was closed and all of the students were forced to attend their learning activities at home, all religious activities were stopped. Baitullah Mosque which is located at the complex of MAN 3 Palembang and regularly held religious activities was only available for local community activities during the pandemic outbreak. Currently, as the implementation of hybrid learning is underway, MAN 3 Palembang also reactivated the regular functions of the mosque for the students. Local Covid-19 Task Force instructed several changes for MAN 3 Palembang and its religious activities, including the changes of the schedule of salat following the new class schedule as the hybrid learning method is implemented.
Under normal situations, Baitullah Mosque was opened for 5-time salat, including subuh, zuhr, asar, magrib, and isya. The students of MAN 3 Palembang who stay at the dormitory were obligated to attend subuh, magrib and isya at the mosque. School activities, in the normal situation, began at 7 a.m. and ended approximately at 3 p.m. The schedule was changed during the period of hybrid learning as the school classes ended as early as noon. Therefore, all of the students now are obligated to attend 5-times salat at the mosque, with no exception.

The adjustment was also made concerning the capacity and the health protocols. Previously, all of the students from both male and female dormitories could have their salat at the mosque. Currently, the mosque is just open for religious activities particularly for male students, while the students from the female dormitory are attending their religious activities in the dormitory hall. Furthermore, in attending religious activities, all of the students, mentors, and other teaching staff are obligated to comply with the health protocols such as wearing the mask and maintaining physical distancing.

\subsubsection{Interaction Pattern}

To analyze the interaction patterns during the implementation of hybrid learning in Islamic boarding school, it could be done by dividing the patterns into four different types: (1) students - students (among students); (2) students - teaching staffs and mentors; (3) students parents or guardians; (4) students - outsiders. The interaction patterns are still considered as one of the processes that determine the output of students' learning. On the other hand, it is acknowledged that the pandemic has created several transformations to the students' interaction patterns [14].

For the interaction among the students, MAN 3 Palembang made several changes such as reducing normal bedroom capacity by $50-75 \%$. Covid-19 Task Force also suggested MAN 3 Palembang expand the existing bedroom location to reduce the risk of the virus spread. However, it turns out that this change was not 
quite significant to reduce the interaction among the students because they could still easily interact with other students from different bedrooms within the dormitory. Therefore, to make this regulation more effective, the dormitory mentors were instructed to be fully aware of the student's health condition and make sure that they make no interaction with outsiders.

The monitoring responsibility given to the dormitory mentors means that there will be more interaction among them and the students. The principal of MAN 3 Palembang stated that the dormitory mentors should be able to make the students be more comfortable. On the other hand, the mentors should not neglect their main responsibility to build students' discipline and punctuality.

The dormitory mentors should also be a bridge to connect the students and their parents virtually. Most of the mentors told that during the period of the implementation of hybrid learning, they gave more time and opportunity for the students that would like to meet their parents virtually compared to what they gave during the normal situation. They fully acknowledged that their parents are the person who knows the students best and needs to interact with them. Meanwhile, MAN 3 Palembang itself reduced parents' visit during this period of hybrid learning. Every student could only be visited by one family member that has been vaccinated.

Another form of interaction was from the outsiders. Usually, MAN 3 Palembang would give permissions for the students who would like to go out of the dormitory for a clear reason. The students also should be coming back by 5 p.m. Otherwise, they will receive a punishment. Currently, MAN 3 Palembang restricts this rule and does not permit the students to leave the dormitory, except accompanied by their parents or guardians. This rule is also applied to the dormitory mentors and teaching staff.

\subsubsection{Learning Pattern}

As an Islamic Boarding School, MAN 3 Palembang established the Islamic curriculum to be taught within the dormitory. That includes: (1) tilawatil Qur'an; (2) tahfidzul Qur'an; (3) tahsin; (4) qirro'atul qutub; (5) Arabic; and (6) English. The learning activities begin after Magrib praying time and continue after Isya praying time until around 9 p.m. In participating in those activities, the students were divided into several groups, consisting of 15-20 people per group. Each group had its own schedule and be taught by different teaching staff from Sunday to Friday. After attending the learning activities in the evening, the students also attended the school class which takes place from 7 am to $3 \mathrm{pm}$.

During the implementation of hybrid learning, some adjustments were made. The division of each group during evening learning activities was reduced from 15-
20 people to only $10-15$ people in each group. MAN 3 Palembang also ruled that the class should only be attended by $25 \%$ of students compared to its normal capacity. It means the students only went to the school three times a week, and the remaining days of classes were attended through the online learning method. Another change made was concerning the ownership of gadgets during the students staying at the dormitory. In a normal period, students were not permitted to bring Smartphone and other related gadgets, except for laptops. During the implementation of the hybrid learning method, the students were allowed to have their Smartphone to attend online classes but also required to resubmit their Smartphone back to each rooms' mentor after finishing the online class.

The learning process was not just happening within the school or evening class, but also concerning the students' daily life. As an educational institution, MAN 3 Palembang has the highest responsibility to guide its students to have good behavior and attitude [15]. All of the teaching staff and the dormitory mentors should be able to guide their students concerning this issue.

In guiding the students, it implicates that they have to be role models. They have to pray on time, speak the proper words, and be neatly dressed. Those practices are slowly imitated by some of the students in their daily life. Unfortunately, some of the students still show no attention to imitating their teachers and mentors and violate several rules regarding tidiness, including wearing an incorrect school uniform and wearing t-shirts while going outside his/her room. The responsible mentors or teachers would note some of those students to later be reported and processed.

Another form of discipline built by MAN 3 Palembang for the students' daily life is to be punctual. Since studying from home, most of the students were given freedom by their parents. However, staying at the dormitory means that the students have to leave that freedom behind and comply with the existing schedules. In the morning, the students had to wake up as early as 4 a.m. to go to the mosque and pray and then went for a shower and had breakfast before going to school or attending online classes starting at $6.30 \mathrm{am}$. Some of the students should also follow the picket schedule and clean up their rooms. After finishing school, the students were having free time until the evening activities begin. As the evening activities finished at 9 p.m., the students could utilize the remaining time to study privately before going to sleep at 10 p.m.

It was admitted that most of the students are still adapting to be on time. The dormitory mentors and teaching staff would always guide them and make sure that they are not going to be late. Therefore, students' activity and punctuality are always monitored. The students that have violated the rules would be given several punishments. In the end, most of the mentors and 
teaching staff believe that their students could adapt well and be punctual. However, they also acknowledge that it would take a slightly longer time.

\section{RESULTS AND DISCUSSION}

This study notes several challenges faced by MAN 3 Palembang as an Islamic boarding school in implementing the hybrid learning method. Concerning the preparedness of learning infrastructures and facilities, some of them are found to be exhausting and require a regular check from the responsible parties. There is also a growing concern of paradigm shift among the students, dormitory mentors, teaching staff, and even the students' parents and guardians. However, it is acknowledged that to face the paradigm shift, all parties should work cooperatively to achieve the goal of sustaining high-level education. The challenges to implement the hybrid learning method also occurred in three different patterns: worshipping, interaction, and learning aspects. The words "hybrid" means that all of those activities should be done by combining directly the online/remote learning methods. Therefore, MAN 3 Palembang as an Islamic boarding school is demanded to be creative and adaptive [15].

The principal and some of the teaching staff also admitted that a short adaptation time and no opportunity to do a trial of this new learning method becomes another obstacle. The preparation of implementing the hybrid learning method only last 1-2 weeks, including the meeting, announcement, and repairing of the required infrastructures. This obstacle was even more challenging for the Islamic boarding school due to the need of preparing two different environments: the school and the dormitory. Besides the obstacles, the implementation of the hybrid learning method in MAN 3 Palembang is also sustained by several supporting factors. One of the most important factors is high support from the students' parents as well as the school committee. Both parties have acknowledged the students' desire to go back to school. Therefore, when MAN 3 Palembang announced that the students would be ordered to stay at the dormitory, they received no resistance from the students' parents. Another supporting factor is the cooperation from the regional Ministry of Religious Affairs that highly supports the implementation. The schools are given the independence to develop their own policies to implement the new learning method.

\section{CONCLUSIONS}

This study ended with several conclusions. First, the implementation of hybrid learning in MAN 3 Palembang is based on some specified indicators provided by the government including the preparation of learning facilities and infrastructures, paradigm, religious activities, interaction pattern, and learning patterns. Each of those indicators has its own implications for the sustainability of the learning process in Islamic boarding schools during the post-Covid era. Several things such as the exhausting infrastructures, paradigm shift, a demand to be more creative, and high interaction are the obstacles. However, the implementation of the hybrid learning method is also supported by the desire of the responsible parties to work cooperatively and the independence given by the government to every Islamic boarding school to develop their own method.

This study also would like to give several recommendations to improve the implementation of the hybrid learning method in Islamic boarding schools, for various responsible parties including the policymakers of the school, school residents, dormitory regulators, and government, committees, and the parents. For Indonesian madrasah, both policymakers of the school and the residents should optimize their cooperative work to sustain the implementation of hybrid learning policies. Both parties have a freedom to choose different method of implementations, but the policy-makers have to ensure that a set of strict policies will be implemented. On the other hand, the school residents must be able to be reactive and report any kind of changes that could burden the implementation. Dormitory regulators also play an important role. They have to be aware responsible for the students' facilities condition. Proper facilities become an essential determinant, noting that most of the students' daily activities are spent within the dormitory complex. The government, school committees, and the parents also have the responsibility to check and monitor the existing facilities within the classes and the dormitory.

\section{AUTHOR CONTRIBUTIONS}

The author conceived and designed this study and contributed to the process of revising the manuscript, and at the end, the author has approved the final version of this manuscript.

\section{REFERENCES}

[1] Z.N. Khlaif, S. Salha, The Unanticipated Educational Challenges of Developing Countries in Covid-19 Crisis: A Brief Report, Interdisciplinary Journal of Virtual Learning in Medical Sciences, 11(2) (2020) 130-134.

[2] Joharudin, M A. Septiadi, S. Maharani, Panic Syndrom Covid-19: Penekanan terhadap Kebijakan yang Diberikan, Jurnal Perspektif, 4(1) (2020) 44 53.

[3] D. R. Khasanah, H. Pramudibyanto, B. Widuroyekti, Pendidikan dalam Masa Pandemi Covid-19, Jurnal Sintesia, 10(1) (2020) 41-48.

[4] R. Setiawan, E. Komalasari, Membangun Efektifitas Pembelajaran Sosiologi di Tengah 
Pandemi Covid-19, Jurnal Ilmiah Penelitian Pendidikan dan Sosiologi, 4(1) (2020) 1-13.

[5] D. Noer, Gerakan Modern Islam di Indonesia. Jakarta: LP3ES, 1995.

[6] Kementerian Agama Republik Indonesia. Surat Edaran Nomor B2733.1/DJ.I/PP.00/.00.11/08/2021 tentang Panduan Penyelenggaraan Pembelajaran pada Madrasah, Pesantren, dan Lembaga Pendidikan Keagamaan Islam Pada Masa Pemberlakuan Pembatasan Kegiatan Masyarakat Coronavirus Disease 2019. 2021.

[7] R. Ananda, Perencanaan Pembelajaran. Jakarta: Lembaga Peduli Pengembangan Pendidikan Indonesia, 2019.

[8] J.W. Creeswell, A. Tashakkori, Differing Perspectives on Mixed Method Research, 303-308, 2007.

[9] M. Reeves, P. Carlsson-Szlezak, K. Whitaker, and M. Abraham, Sensing and Shaping the Post-COVID Era. The BCG Henderson Institute, 2020.

[10] L. Espino-Diaz, G. Fernandez-Caminero, C. Hernandez-Lloret, H. Gonzalez, J. A. Castillo, Analyzing the Impact of COVID-19 Education Professionals. Toward a Paradigm Shift: ICT and Neuroeducation as a Binomial of Action, Sustainability, 12(1) (2020) 1-10.

[11] K. Abror, Fiqh Ibadah. Bandar Lampung: Phoenix Publisher, 2019.

[12] E. Purba, D. Handayani, M. Magdalena, N. Sarumaha, H. Wiryadinata, Redefinisi Ibadah pada Masa Pandemi Covid-19, Jurnal Teologi Berita Hidup, 4(1) (2021) 36-46..

[13] K. Z. Putro, M. A. Amri, N. Wulandari, D. Kurniawan, Interaksi Anak dan Orangtua selama Kebijakan Pembelajaran di Rumah' Fitrah: Journal of Islamic Education, 1(1) (2020) 124-140.

[14] S. Sagala, Manajemen dan Kepemimpinan Pendidikan Pondok Pesantren, Jurnal Tarbiyah, 22(2) (2015).

[15] P. Goodyear, Design and Co-Configuration for Hybrid Learning: Theorising the Practices of Learning Space Design, British Journal of Educational Technology, 51(4) (2020) 1045-1060. 